\title{
PENERAPAN PSAK NO.30 MENGENAI PERLAKUAN AKUNTANSI SEWA DAN PENGARUHNYA PADA LAPORAN KEUANGAN PT. BFI FINANCE INDONESIA, TBK.
}

\author{
Asep Alipudin $^{*}$ dan Rati Pitria Ningsi**)
}

\begin{abstract}
ABSTRAK
Penelitian ini bertujuan untuk mengetahui (1) Perlakuan transaksi sewa yang dicatat oleh PT. BFI Finance Indonesia, Tbk. selama periode leasing, (2) Membandingkan perlakuan akuntansi sewa selama periode leasing antara yang dilakukan oleh PT. BFI Finance Indonesia, Tbk. dengan PSAK No. 30, (3) Mengetahui dampak perlakuan akunatansi sewa yang dilakukan oleh PT. BFI Finance Indonesia, Tbk. terhadap Laporan Keuangan Perusahaan. Hasil penelitian yang dilakukan diperoleh hasil bahwa perlakuan akuntansi yang diterapkan PT. BFI Finance Indonesia, Tbk. atas aset yang diperoleh melalui kegiatan pembiayaan adalah dengan menggunakan metode sewa pembiayaan (capital lease) dan di depresiasi dengan metode garis lurus atau straight line method. Perlakuan sebagai capital lease ini sudah sesuai dengan PSAK No. 30 akan tetapi dalam pencatatan transaksi sewa oleh perusahaan menunjukkan adanya kesalahan pencatatan dan pengelompokkan perkiraan. Hal ini akan mempengaruhi terhadap kewajaran penyajin laporan keuangan oleh karena itu diperlukan jurnal penyesuaian untuk mengoreksi kesalahan-kesalahan tersebut.
\end{abstract}

Kata Kunci: Penerapan PSAK No. 30

\begin{abstract}
This study was to determine (1) The treatment of lease transactions recorded by PT. BFI Finance Indonesia, Tbk. during the leasing period, (2). Comparing the accounting treatment of lease during the leasing period between conducted by PT. BFI Finance Indonesia, Tbk. with SFAS No. 30 (3). Knowing the impact of lease accounting treatment carried out by PT. BFI Finance Indonesia, Tbk to the Company's Financial Statements. This type of research that used in this research is quantitative descriptive analysis (non-statistical). The data that used were the financial statements. BFI Finance Indonesia, Tbk. during the period 2011 to 2013, the independent variable SFAS No. 30 regarding the accounting treatment of leases. The dependent variable is the effect on the financial statements BFI Finance Indonesia, Tbk. The research is shows that the accounting treatment applied by PT. BFI Finance Indonesia, Tbk on assets acquired through financing activities is by using finance leases (capital leases) and in depreciation by the straightline method or straight-line method. Treatment as a capital lease is in accordance with SFAS No. 30 but in the lease transaction recording by the company shows the approximate recording errors and grouping. This will affect the fairness of the financial statements performance therefore necessary adjusting entries to correct those mistakes.
\end{abstract}

Keywords: Adoption of PSAK No. 30

\footnotetext{
${ }^{*}$ Dosen Tetap Fakultas Ekonomi Universitas Pakuan

${ }^{* *}$ Mahasiswa Fakultas Ekonomi Universitas Pakuan
} 


\section{Pendahuluan}

Dalam perusahaan pembiayaan, aset merupakan bagian penting dari kekayaan yang dimiliki oleh perusahaan, karena aset memiliki proporsi yang terbesar dari kekayaan tersebut. Aset adalah aset yang jangka waktu pemakaiannya lama digunakaan dalam kegiatan perusahaan, dimiliki tetapi tidak untuk dijual lagi dalam kegiatan perusahaan,serta nilainya cukup besar. Aset tersebut dapat berupa tanah,bangunan,perlengkapan, dan lain sebagainya. Pengadaan aset ini dapat dipenuhi oleh perusahaan dalam bentuk sewa atau leasing.

Dalam rangka pengembangan perusahaan, biasanya perusahaan akan selalu berusaha untuk mengganti aset yang lam dengan aset yang baru. Penggantian atas aset yang lama ini mungkin disebabkan karena aset telah abis umur ekonomis atau karena rusak dan tidak dapat lagi digunakan dalam kegiatan operasional perusahaan. Sedangkan disisi lain, kegiatan operasional perusahaan menuntut adanya pengadaan aset yang baru terutama tanah, gedung dan peralatan. Pengadaan tetap ini dapat dipenuhi oleh perusahaan dalam bentuk sewa atau leasing.

Penggunaan sewa sebagai sarana mengalihkan hak untuk menggunakan suatu harta kepada kepada pihak lain telah mengalami pertumbuhan yang pesat, hal ini disebabkan semakin menyebarnya jenis aset yang dapat disewa mulai dari kendaraan dan alatalat berat. Hadirnya perusahaan sewa ini semakin mempopulerkan dan menambah kiprah kegiatan bisnis sewa sebagai sumber pembiayaan lain disamping cara-cara pembiayaan konvensional yang lazim dilakukan melalui perbankan. Melihat semakin berkembangnya kegiatan sewa, maka dirasakan adanya kebutuhan untuk menyediakan suatu standar akuntansi keuangan yang dapat dijadikan sebagai pedoman untuk mencatat dan melaporkan transaksi sewa dalam laporan keuangan, sehingga akan dihasilkan suatu laporan keuangan yang wajar dan informasi yang berguna bagi para pemakai laporan keuangan.

Kegiatan sewa diklasifikasi dari segi lessee capital lease (finance lease) dan operating lease. Sedangkan sewa dari segi lessor terdiri dari capital lease (finance lease) dan operating lease, perlakuan akuntansi untuk transaksi sewa perlu diterapkan secara konsisten sesuai dengan PSAK No.30 dalam rangka penyusunan laporan keuangan perusahaan. Untuk itu guna menjawab berbagai pertentangan dan menjelaskan praktek sewa perlu perkajian dari sisi konsep-konsep akuntansi yang mendasar, sehingga dapat ditentukan perlakuan setiap transaksi sewa guna usaha secara tepat, dapat dimengerti, dapat diperbandingkan dan sesuai dengan tujuan laporan keuangan.

PT BFI Finance Indonesia, Tbk. adalah salah satu perusahaan pembiayaan yang pertama kali menjadi perusahaan publik di tahun 1990. BFI memfokuskan kegiatan bisnisnya pada pembiayaan kendaraan-kendaraan roda empat dan dua, dengan target ke masyarakat golongan ekonomi menengah dan menengah ke bawah. Perusahaan juga membiayai alat-alat berat melalui Sewa Pembiayaan. Dan menjadi salah satu dari perusahaanperusahaan pembiayaan dengan bisnis paling beragam di negeri ini.

Laporan keuangan yang merupakan hasil akhir dari proses akuntansi tersebut harus dapat memberikan suatu rangkaian historis dari sumber-sumber ekonomi, kewajiban-kewajiban perusahaan serta kegiatan-kegiatan yang mengakibatkan perubahan-perubahan terhadap sumber- 
sumber ekonomi dan kewajibankewajiban tersebut. Sehingga informasi yang dihasilkan dari laporan keuangan tersebut akan dapat dijadikan sebagai dasar pengambilan keputusan perusahaan untuk periode akuntansi berikutnya.

Oleh karena itu, pencatatan dan pelaporan transaksi sewa yang sesuai dengan ruang lingkup dan karakteristiknya dalam laporan keuangan perusahaan harus mengacu pada pedoman standar akuntansi keuangan yang berlaku yaitu, PSAK No.30.

Adapun tujuan dari penelitian yang ingin dicapai penulis dalam penelitian ini adalah 1) Mengetahui perlakuan transaksi sewa yang dicatat oleh PT BFI Finance Indonesia, Tbk. selama periode leasing; 2) Membandingkan perlakuan akuntansi sewa selama periode leasing antara yang dilakukan oleh PT BFI Finance Indonesia, Tbk. dengan PSAK No.30; dan 3) Mengetahui dampak perlakuan akuntansi sewa yang dilakukan oleh PT BFI Finance Indonesia, Tbk. terhadap laporan keuangan perusahaan.

\section{Landasan Teori}

Menurut IAI (revisi 2007) Tujuan Pernyataan SAK 30 ini adalah untuk mengatur kebijakan akuntansi dan lessee maupun lessor dalam hubungannya lease. pengungkapan yang sesuai, baik bagi dengan sewa. Sewa (lease) adalah suatu perjanjian dimana lessor memberikan hak kepada lessee untuk menggunakan suatu aset selama periode waktu yang disepakati. Sebagai lessor. imbalannya, lessee melakukan pembayaran atau serangkaian pembayaran kepada lessor.

Menurut IAI (revisi 2011) Tujuan Pernyataan SAK 30 ini adalah untuk mengatur kebijakan akuntansi dan pengungkapan yang sesuai, baik bagi lessee maupun lessor dalam hubungannya dengan sewa.

Maka dari tujuan diatas yang diberikan IAI dapat disimpulkan bahwa tujuan dari PSAK 30 merupakan mengatur kebijakan akuntansi untuk mengatur dan pengungkapan sesuai bagi lessee maupun lessor dalam hubungannya tentang sewa

\section{Metodelogi Penelitian}

Jenis penelitian yang digunakan penulis adalah penelitian deskriptif kuantitatif. Penelitian deskriptif adalah penelitian yang menggambarkan suatu fenomena dengan jalan mendeskripsikan sejumlah variabel yang berkenaan dengan masalah yang diteliti.

Dalam penelitian ini penulis menggunakan teknik penelitian non statistik komparatif, yaitu teknik penelitian yang digunakan terhadap penelitian dengan membandingkan data-data dari periode setelah dan sebelum penerapan PSAK No.30. Dalam melakukan penelitian ini yang menjadi objek penelitian adalah penerapan PSAK No. 30 mengenai perlakuan akuntansi sewa dan pengaruhnya pada laporan keuangan PT BFI Finance Indonesia, Tbk .

Data yang digunakan adalah data laporan keuangan periode tahun 20112013 tahunan yang meliputi laporan posisi keuangan dan laporan laba rugi pada perusahaan yang di ambil dari Bursa Efek Indonesia (www.idx.co.id) dan homepage PT BFI Finance Indonesia, Tbk.Unit analisis yang digunakan dalam penelitian ini adalah berupa organization yaitu sumber data yang unit analisisnya merupakan respon dari devisi organisasi/perusahaan. Sumber data yang digunakan dalam penelitian ini adalah data sekunder.

Data sekunder (secondary data) merupakan sumber yang tidak langsung 
memberikan data kepada pengumpul data, jadi penulis untuk mendapatkan data dan informasi melalui BEI dan situs resmi perusahaan. Pengumpulan data yang dilakukan penulis yaitu penelitian kepustakaan, penelitian lapangan, wawancara.

Penelitian ini dilakukan dengan menggunakan metode analisis deskriptif (non statistik), yaitu dengan menggambarkan keadaan pada saat penerapan dan sebelum penerapan PSAK No.30 penelitian ini dilakukan dengan riset teori yang kemudian diterapkan dengan pengukuranpengukuran yang sesuai PSAK No.30 sebagai alat analisis.

\section{Hasil Penelitian}

4.1. Perlakuan Akuntansi Sewa PT BFI Finance Indonesia, Tbk. Dibandingkan Dengan PSAK No 30.

Dari pencatatan transaksi terlihat bahwa perlakuan akuntansi terhadap transaksi sewa yang dilakukan perusahaan tergolong kedalam capital lease, hal ini dikarenakan beberapa syarat yang terdapat dalam perjanjian sewa yang dilakukan oleh perusahaan sesuai dengan PSAK No 30 paragraf 03 yaitu sebagai berikut :

1. Penyewa memiliki hak opsi untuk membeli aset yang disewa pada akhir masa sewa dengan harga yang telah disetujui bersama pada saat dimulainya perjanjian sewa.

2. Seluruh pembayaran berkala yang dilakukan oleh penyewa ditambah dengan nilai sisa mencakup pengembalian harga perolehan barang modal yang disewa serta bunganya sebagai keuntungan perusahaan sewa.

3. Masa sewa minimum 2 tahun.

Dari penjelasan diatas yang memenuhi kriteria capital lease, jadi melalui identifikasi ini dapat diketahui bahwa transaksi sewa yang dilakukan oleh PT BFI Finance Indonesia, Tbk. tergolong capital lease.

\subsection{Perlakuan Akuntansi Sewa Modal (Capital Lease) Menurut PSAK No. 30.}

\section{Simpanan Jaminan}

Dari jurnal yang dibuat terlihat bahwa perusahaan memperlakukan simpanan jaminan sebagai uang muka, padahal simpanan jaminan bagi lesse merupakan harta yang pada akhir masa sewa akan dipergunakan sebagai hak opsi pembelian untuk membeli peralatan sebesar Rp. 76.368.120 .

Jurnal yang tepat pada saat membayar jaminan adalah:

D. Pendapatan diterima

$$
\text { dimuka Rp. 76.368.120 }
$$

K. Piutang sewa Rp. 76.368.120

(untuk mencatat simpanan jaminan)

\section{Pencatatan Aset Lancar Sewa}

Dengan menggunakan metode capital lease, maka perusahaan akan mencatat harga perolehan peralatan sebagai aset yang selanjutnya akan diamortisasi selama umur ekonomisnya. Dalam penyajian aset sewa perusahaan telah menjurnal perolehan peralatan yang disewa sebagai kelompok aset lancar tanpa memisahkan dengan aset lancar lain yang bukan aset sewa, sehingga di dalam laporan posisi keuangan tidak tampak nilai perolehan sebenarnya.

Berdasarkan PSAK No 30 paragraf 07 tentang perlakuan akuntansi sewa dinyatakan sebagai berikut, aset lancar yang disewa dilaporkan sebagai bagian aset lancar dalam kelompok tersendiri, piutang sewa yang bersangkutan harus disajikan terpisah dari piutang lainnya.

Pencatatan perolehan yang lebih tepat berdasarkan PSAK No 30 
seharusnya dijurnal terpisah sebagai kelompok aset, sebagai berikut :

D. Piutang Pembayaran Sewa xxx

K. Peralatan Sewa xxx

Oleh karena itu perlu jural koreksi terlebih dahulu untuk mengeliminasi saldo peralatan sewa yang dikelompokkan dalam aset lancar perusahaan :
D. Kas
Rp. 305.472.624
K. Piutang Sewa
Rp.
(untuk mencatat jurnal reklasifikasi perolehan peralatan)

Sehingga jurnal yang seharusnya dicatat oleh perusahaan akan berubah sebagai berikut :
D. Piutang Pembayaran
Sewa Rp. 305.472.624
K. Peralatan Sewa
305.472.624

Rp.

\subsection{Pencatatan \\ Depresiasi Aset Sewa}

Sesuai PSAK No. 30 paragraf 5 dinyatakan bahwa, Aset yang disewa harus diamortisasi dalam jumlah yang wajar berdasarkan teksiran masa manfaatnya.

Perusahaan telah menggunakan metode garis lurus dalam menentukan beban depresiasi atas peralatan dan umur ekonomisnya 5 tahun. Dalam pencatatan akumulasi depresiasi peralatan, perusahaan mendebet beban depresiasi peralatan dan mengkredit akumulasi depresiasi peralatan sebesar Rp. 61.094.524 tanpa memisahkan antara peralatan sewa dan peralatan bukan sewa.

Hal ini kurang tepat, seharusnya peralatan tersebut dicatat dalam perkiraan tersendiri pada kelompok aset sewa dan bukan kelompok aset tetap.

Jurnal yang seharusnya dibuat oleh perusahaan adalah :

D. Beban Depresiasi Peralatan

$$
\text { Sewa Rp. 61.094.524 }
$$

K. Akm.Depresiasi Peralatan

$$
\text { Sewa Rp.61.094.524 }
$$

(untuk mencatat akumulasi depresiasi peralatan sewa).

Sedangkan pada saat melaporkan beban depresiasi peralatan perusahaan telah mencatat pada kelompok beban usaha, hal ini sudah tepat sehingga tidak diperlukan jurnal koreksi. Untuk mengetahui lebih rinci berkaitan dengan depresiasi aset sewa dapat dilihat pada tabel 5 .

Tabel 1

Skedul Beban Depresiasi, Akumulasi Depresiasi dan Nilai Buku Aset Sewa (Rp)

\begin{tabular}{|c|c|c|c|c|}
\hline No & Periode & $\begin{array}{c}\text { Beban } \\
\text { Depresiasi }\end{array}$ & $\begin{array}{c}\text { Akumulasi } \\
\text { Penyusutan }\end{array}$ & $\begin{array}{c}\text { Nilai } \\
\text { Buku }\end{array}$ \\
\hline & & & & $305,472,624$ \\
\hline 1 & Mar-11 & $3,460,132$ & $3,460,132$ & $302,012,492$ \\
\hline 2 & Apr-11 & $3,460,132$ & $6,920,264.00$ & $298,552,360$ \\
\hline 3 & $\begin{array}{c}\text { May- } \\
11\end{array}$ & $3,460,132$ & $10,380,396.00$ & $295,092,228$ \\
\hline 4 & Jun-11 & $3,460,132$ & $13,840,528.00$ & $291,632,096$ \\
\hline 5 & Jul-11 & $3,460,132$ & $17,300,660.00$ & $288,171,964$ \\
\hline 6 & Aug-11 & $3,460,132$ & $20,760,792.00$ & $284,711,832$ \\
\hline 7 & Sep-11 & $3,460,132$ & $24,220,924.00$ & $281,251,700$ \\
\hline 8 & Oct-11 & $3,460,132$ & $27,681,056.00$ & $277,791,568$ \\
\hline
\end{tabular}

JIAFE (Jurnal Ilmiah Akuntansi Fakultas Ekonomi)

Volume 1 No. 2 Tahun 2015, Hal. 51-62 


\begin{tabular}{|c|c|c|c|c|}
\hline 9 & Nov-11 & $3,460,132$ & $31,141,188.00$ & $274,331,436$ \\
\hline 10 & Dec-11 & $3,460,132$ & $34,601,320.00$ & $270,871,304$ \\
\hline 11 & Jan-12 & $3,460,132$ & $38,061,452.00$ & $267,411,172$ \\
\hline 12 & Feb-12 & $3,460,132$ & $41,521,584.00$ & $263,951,040$ \\
\hline 13 & Mar-12 & $3,460,132$ & $44,981,716.00$ & $260,490,908$ \\
\hline 14 & Apr-12 & $3,460,132$ & $48,441,848.00$ & $257,030,776$ \\
\hline 15 & $\begin{array}{c}\text { May- } \\
12\end{array}$ & $3,460,132$ & $51,901,980.00$ & $253,570,644$ \\
\hline 16 & Jun-12 & $3,460,132$ & $55,362,112.00$ & $250,110,512$ \\
\hline 17 & Jul-12 & $3,460,132$ & $58,822,244.00$ & $246,650,380$ \\
\hline 18 & Aug-12 & $3,460,132$ & $62,282,376.00$ & $243,190,248$ \\
\hline 19 & Sep-12 & $3,460,132$ & $65,742,508.00$ & $239,730,116$ \\
\hline 20 & Oct-12 & $3,460,132$ & $69,202,640.00$ & $236,269,984$ \\
\hline 21 & Nov-12 & $3,460,132$ & $72,662,772.00$ & $232,809,852$ \\
\hline 22 & Dec-12 & $3,460,132$ & $76,122,904.00$ & $229,349,720$ \\
\hline 23 & Jan-13 & $3,460,132$ & $79,583,036.00$ & $225,889,588$ \\
\hline 24 & Feb-13 & $3,460,132$ & $83,043,168.00$ & $222,429,456$ \\
\hline 25 & Mar-13 & $3,460,132$ & $86,503,300.00$ & $218,969,324$ \\
\hline 26 & Apr-13 & $3,460,132$ & $89,963,432.00$ & $215,509,192$ \\
\hline 27 & $\begin{array}{c}\text { May- } \\
13\end{array}$ & $3,460,132$ & $93,423,564.00$ & $212,049,060$ \\
\hline 28 & Jun-13 & $3,460,132$ & $96,883,696.00$ & $208,588,928$ \\
\hline 29 & Jul-13 & $3,460,132$ & $100,343,828.00$ & $205,128,796$ \\
\hline 30 & Aug-13 & $3,460,132$ & $103,803,960.00$ & $201,668,664$ \\
\hline 31 & Sep-13 & $3,460,132$ & $107,264,092.00$ & $198,208,532$ \\
\hline 32 & Oct-13 & $3,460,132$ & $110,724,224.00$ & $194,748,400$ \\
\hline 33 & Nov-13 & $3,460,132$ & $114,184,356.00$ & $191,288,268$ \\
\hline 34 & Des-13 & $3,460,132$ & $117,644,488.00$ & $187,828,136$ \\
\hline 35 & Jan-14 & $3,460,132$ & $121,104,620.00$ & $184,368,004$ \\
\hline 36 & Feb-14 & $3,460,132$ & $124,564,752.00$ & $180,907,872$ \\
\hline
\end{tabular}

Sumber : PT BFI Finance Indonesia, Tbk. (data diolah)

Dari tabel 1 di atas tampak bahwa perusahaan mencatat transaksi perolehan peralatan sebagai aset tetap, sehingga setiap akhir tahun perusahaan harus menyusutkan peralatan selama periode berjalan. Dalam menghitung depresiasi, perusahaan menggunakan meode depresiasi garis lurus dengan umur ekonomis 5 tahun tanpa nilai sisa. Dengan adanya skedul tersebut, maka akan mempermudah perusahaan untuk mengetaui nilai buku peralatan sewa setiap akhir periode sewa ataupun hingga peralatan tersebut ditarik dari penggunaanya.

\subsection{Pencatatan dan Penetapan Beban Bunga}

Dari perhitungan yang telah dilakukan oleh perusahaan seperti yang ditunjukkan pada tabel 3, terlihat bahwa perusahaan menetapkan beban bunga yang dicatat pada setiap periode saat pembayaran angsuran dengan tidak memperhatikan nilai waktu uang (time value of money) sehingga mempunyai 
nilai tetap yaitu sebesar Rp. 3.460.132, demikian juga dengan pencatatan angsuran pokok ditetapkan dengan jumlah yang tetap sebesar Rp. 6.364.014 . Dari tabel 3 juga dapat dihitung berapa tingkat bunga yang ditentukan oleh perusahaan, mengingat lessor tidak menetapkan tingkat bunga sewa. Tingkat bunga sewa oleh perusahaan dihitung sebagai berikut :

$$
\begin{aligned}
& =\frac{\text { Beban selama masa sewa }}{\text { Saldo awal hutang }} \times 100 \% \\
& =\frac{\text { Rp.430.037-Rp.305.472.624 }}{\text { Rp. } 305.472 .624-\text { Rp. } 76.368 .120} \times 100 \% \\
& =\frac{\text { Rp. } 124.564 .752}{\text { Rp. } 229.104 .504} \times 100 \% \\
& =0,54 \% / 36 \text { bulan } \\
& =0,0151 \%
\end{aligned}
$$

Dengan melihat perhitungan tersebut menunujukkan bahwa perusahaan tidak menerapkan nilai waktu uang. Seharusnya pembayaran angsuran setiap bulan sebesar Rp. 9.824.146 merupakan pembayaran angsuran kewajiban pokok dan pembayaran beban bunga pada prosentase tertentu atas sisa kewajiban yang harus dipenuhi. Jadi sebaiknya perusahaan menghitung beban bunga untuk lessee berdasarkan metode anuitas yang memperhatikan nilai waktu uang.

Dalam PSAK No.30 paragraf 5.1 , dinyatakan bahwa tingkat diskonto yang ditentukan untuk menentukan nilai tunai dari pembayaran sewa adalah tingkat bunga yang dibebankan oleh perusahaan sewa atau tingkat bunga yang berlaku pada awal masa sewa.

Berdasarkan keterangan dari PSAK No.30 di atas jelas bahwa tingkat bunga yang ditetapkan harus didiskontokan untuk mengubah nilai uang dimasa yang akan datang menjadi nilai sekarang dengan metode anuitas. berikut :

Rumus metode anuitas sebagai

$P=F\left[\frac{1-\frac{1}{(1+i)^{n}}}{i}\right]$
Keterangan :

P : Nilai Pembayaran (Nilai Kontrak Neto)

F: Besarnya Angsuran Pembayaran Sewa Tiap Periode

I : Tingkat Bunga Tiap Periode

n : Jumlah Periode Pembayaran Sewa Maka berdasarkan variabelvariabel diatas, tingkat bunga berlaku pada perusahaan dapat dihitung $\mathrm{P}$ (nilai pembayaran) sebesar Rp. 229.104.504 diperoleh dari harga perolehan dikurangi dengan simpanan jaminan (Rp. 305.472.624 - Rp. 76.368.120). F (angsuran pembayaran sewa) sebesar Rp. 9.824.146, jumlah periode pembayaran sewa (n) 3 tahun atau 36 bulan. Jika semua variabel tersebut dimasukkan dalam rumus diatas maka perhitungannya sebagai berikut :

$P=F\left[\frac{1-\frac{1}{(1+i)^{n}}}{i}\right]$

Rp.229.104.504 = Rp.9.824.146 $\left[\frac{1-\frac{1}{(1+i)^{36}}}{i}\right]$

$\frac{\text { Rp. } 229.104 .504}{\text { Rp. } 9.824 .146}=\left[\frac{1-\frac{1}{(1+i)^{36}}}{i}\right]$

$23,32055=\left[\frac{1-\frac{1}{(1+i)^{36}}}{i}\right]$

Setelah itu kita melihat tabel 4, dimana $\mathrm{n}=36$, nilai 23,32055 terletak antara 2\% dan 3\%. Nilai tersebut diinterpolasikan agar lebih mendekati nilai aunitas yang terletak di tabel yaitu $2 \%$.

Interpolasi

$$
\begin{aligned}
& =2 \%+\left(\frac{27,3555-23,3205}{27,3555-23,1148}\right) \times 1 \% \\
& =2 \%+\left(\frac{4,035}{4,2407}\right) \times 1 \% \\
& =2 \%+0,9514938 \% \\
& =2,95 \%
\end{aligned}
$$

Kemudian nilai 2,95 \% dimasukkan kembali kedalam rumus apakah nilai atau tingkat bunga $2,95 \%$ 
mendekati angsuran pembayaran sewa atau lebih besar dari angsuran sewa :

Rp. 9.824.146 $P=F\left[\frac{1-\frac{1}{(1+i)^{n}}}{i}\right]$

$\mathrm{F}=\frac{P \times i \times(1+i)^{n}}{(1+i)^{n}-1}$

$\mathrm{F}=\frac{229.104 .504 \times 0,0295 \times(1+0,0295)^{36}}{(1+0,0295)^{36}-1}$

$\mathrm{F}=\mathrm{Rp} \cdot 10.218 .714$ (terlalu besar)

Kemudian diuji dengan tingkat bunga yang lebih kecil yaitu $2,78 \%$ dengan cara yang sama seperti yang di atas dan hasilnya Rp. 9.829.237 dan selisih sebesar Rp. 5.091 di dapat dari Rp. $\quad 9.829 .237$ - Rp. 9.824.146 disebabkan hasil pembulatan dan dianggap tidak material. Dengan demikian tingkat bunga sewa yang seharusnya ditetapkan oleh perusahaan sebesar $2,78 \%$.

$$
\begin{aligned}
& \mathrm{P}=\mathrm{F}\left[\frac{1-\frac{1}{(1+\mathrm{i})^{\mathrm{n}}}}{\mathrm{i}}\right] \\
& \mathrm{F}=\frac{\square \times \square \times(1+\square)^{\square}}{(1+\square)^{\square}-1} \\
& \mathrm{~F}=\frac{229,104,504 \times 0,0278 \times(1+0,0278)^{36}}{(1+0,0278)^{36}-1} \\
& \mathrm{~F}=\text { Rp. 9.829.237 } \\
& \mathrm{F}=\text { Rp. 9.824.146 (dibulatkan) }
\end{aligned}
$$

Sesuai dengan usulan penulis berarti bunga yang digunakan sekarang adalah tingkat bunga atas dasar anuitas, oleh karena itu perlu diadakan koreksi atas perlakuan beban bunga yang telah dilakukan oleh perusahaan, karena beban bunga berkaitan dengan erat dengan kewajiban sewa yang dibayarkan oleh lessee kepada lessor maka akan dibahas pada sub bab

\begin{tabular}{|c|c|c|c|c|c|c|}
\hline No & Periode & Keterangan & $\begin{array}{l}\text { Pembayaran } \\
\text { lease / bulan }\end{array}$ & $\begin{array}{l}\text { Pendapatan } \\
\text { Bunga }\end{array}$ & $\begin{array}{l}\text { Pembayaran } \\
\text { Pokok }\end{array}$ & $\begin{array}{l}\text { Piutang } \\
\text { Sewa }\end{array}$ \\
\hline & & Saldo Awal & & & & $305,472,624$ \\
\hline 1 & 28-Mar-11 & Penerimaan & $9,824,146$ & $6,369,105$ & $3,455,041$ & $302,017,583$ \\
\hline 2 & 28-Apr-11 & Penerimaan & $9,824,146$ & $6,273,055$ & $3,551,091$ & $298,466,492$ \\
\hline 3 & $\begin{array}{l}28-\text { May- } \\
11\end{array}$ & Penerimaan & $9,824,146$ & $6,174,334$ & $3,649,812$ & $294,816,680$ \\
\hline 4 & 28-Jun-11 & Penerimaan & $9,824,146$ & $6,072,869$ & $3,751,277$ & $291,065,403$ \\
\hline 5 & 28-Jul-11 & Penerimaan & $9,824,146$ & $5,968,584$ & 3,855 , & $287,209,841$ \\
\hline 6 & 28-Aug-11 & Penerimaan & $9,824,146$ & $5,861,399$ & $3,962,747$ & $283,247,094$ \\
\hline 7 & 28-Sep-11 & Penerimaan & $9,824,146$ & $5,751,235$ & 4,07 & $279,174,183$ \\
\hline 8 & 28-Oct-11 & & & & & \\
\hline 9 & 28 & Pen & & & & 35,532 \\
\hline 10 & 28-Dec-11 & Pener & 9,8 & 5,402 & 4,42 & $266,263,410$ \\
\hline & & & $98,241,460$ & $59,032,246$ & 39,2 & \\
\hline 11 & 28-Jan-12 & Penerimaan & $9,824,146$ & $5,279,089$ & $4,545,057$ & $261,718,353$ \\
\hline 12 & 28-Feb-12 & Penerimaan & $9,824,146$ & $5,152,736$ & $4,671,410$ & $257,046,943$ \\
\hline 13 & 28-Mar-12 & & & $5,022,871$ & & $252,245,668$ \\
\hline 14 & 28-Apr-12 & & & & & $247,310,917$ \\
\hline 15 & $\begin{array}{l}\text { 28-May- } \\
12\end{array}$ & & & & & $242,238,980$ \\
\hline 16 & 28-Jun-12 & Penerimaan & & & & $237,026,043$ \\
\hline 17 & 28-Jul-12 & Penerimaan & $9,824,146$ & $4,466,290$ & $5,357,856$ & $231,668,187$ \\
\hline 18 & 28-Aug-12 & Penerimaan & $9,824,146$ & $4,317,341$ & $5,506,805$ & $226,161,382$ \\
\hline 19 & 28-Sep-12 & Penerimaan & $9,824,146$ & $4,164,252$ & $5,659,894$ & $220,501,488$ \\
\hline
\end{tabular}
selanjutnya.

Tabel 2

Skedul Angsuran Pembayaran Sewa Pada

Tingkat Bunga 2,78\% (Rp) 


\begin{tabular}{|c|c|c|c|c|c|c|}
\hline 20 & 28-Oct-12 & Penerimaan & $9,824,146$ & $4,006,907$ & $5,817,239$ & $214,684,249$ \\
\hline 21 & 28-Nov-12 & Penerimaan & $9,824,146$ & $3,845,188$ & $5,978,958$ & $208,705,291$ \\
\hline \multirow[t]{2}{*}{22} & 28-Dec-12 & Penerimaan & $9,824,146$ & $3,678,973$ & $6,145,173$ & $202,560,118$ \\
\hline & & & $117,889,752$ & $54,186,460$ & $63,703,292$ & \\
\hline 23 & 28-Jan-13 & Penerimaan & $9,824,146$ & $3,508,137$ & $6,316,009$ & $196,244,109$ \\
\hline 24 & 28-Feb-13 & Penerimaan & $9,824,146$ & $3,332,552$ & $6,491,594$ & $189,752,515$ \\
\hline 25 & 28-Mar-13 & Penerimaan & $9,824,146$ & $3,152,086$ & $6,672,060$ & $183,080,455$ \\
\hline 26 & 28-Apr-13 & Peneril & & & $6,857,5$ & $176,222,911$ \\
\hline 27 & $\begin{array}{l}\text { 28-May- } \\
13\end{array}$ & $\tan$ & & 2,77 & 7,0 & 728 \\
\hline 28 & 28-Jun-13 & eneri & 9,8 & 2,58 & 7,2 & $, 930,605$ \\
\hline 29 & $28-\mathrm{Ju}$ & Penerimaan & 146 & 2,378 & 7,44 & $154,485,096$ \\
\hline 30 & 28-Aug-13 & Penerimaan & $9,824,146$ & 2,17 & 7,65 & $146,832,601$ \\
\hline 31 & 28-Sep-13 & Penerimaan & $9,824,146$ & $1,958,912$ & 7,86 & $138,967,367$ \\
\hline 32 & 28-Oct-13 & Penerimaan & $9,824,146$ & $1,740,259$ & $8,083,887$ & $130,883,480$ \\
\hline 33 & 28-Nov-13 & & & & 8,3 & $122,574,861$ \\
\hline \multirow[t]{2}{*}{34} & 28-Des-13 & Peneri & 9,824 & 1,28 & 8,53 & 5,262 \\
\hline & & & 89,752 & 29,3 & 4,856 & \\
\hline 35 & 28-Jan-14 & Penerimaan & $9,824,146$ & $1,047,146$ & $8,777,000$ & $105,258,262$ \\
\hline 36 & 28-Feb-14 & Penerimaan & $9,824,146$ & 803,145 & $9,021,001$ & $96,237,261$ \\
\hline \multirow[t]{3}{*}{37} & 28-Mar-14 & Penerimaan & $76,368,120$ & $19,869,141$ & $96,237,261$ & 0 \\
\hline & & & $96,016,412$ & $21,719,432$ & $114,035,262$ & \\
\hline & & & $430,037,376$ & $164,303,034$ & $305,472,624$ & \\
\hline
\end{tabular}

Sumber : PT BFI Finance Indonesia, Tbk. (data diolah)

Tabel 2 di atas menjelaskan tentang usulan penulis untuk menggunakan metode anuitas dalam perhitungan beban bunga sewa, dengan demikian beban bunga pada lessee akan semakin menurun seiring dengan menurunnya piutang sewa. Disamping itu besarnya penerimaan pembayaran pokok sewa semakin besar dengan semakin mengecilnya beban bunga (lessee), hal ini disebabkan karena besarnya bunga dihitung berdasarkan saldo piutang saldo piutang sewa yang semakin kecil sehingga beban bunga untuk lessee yang dicatat juga semakin kecil. Tarif bunga yang ditetapkan sebesar 2,78\% atas saldo piutang sewa yang harus dilunasi oleh perusahaan hingga periode sewa berakhir.

\subsection{Perbandingan Pengaruh Perlakuan Akuntansi Sewa Yang Diterapkan Oleh Perusahaan Dengan Perlakuan Akuntansi Menurut PSAK No.30 Pada Laporan Keuangan. \\ Dari uraian-uraian diatas} sebelumnya, maka dapat diperbandingkan perlakuan akuntansi sewa yang diterapkan oleh perusahaan dengan perlakuan akuntansi menurut PSAK No.30, untuk lebih jelasnya perbedaan-perbedaan financial yang terjadi dan berkaitan dengan transaksi sewa seperti terlihat pada tabel 8 dan tabel 9 berikut : 
Tabel 3

Pengaruh Transaksi Sewa Pada Laporan

Posisi Keuangan (Rp)

\begin{tabular}{|c|c|c|c|c|}
\hline \multirow{2}{*}{ Tanggal } & \multicolumn{2}{|c|}{ Sebelum } & Penyesuaian & \multicolumn{2}{c|}{ Sesudah } & Penyesuaian \\
\cline { 2 - 5 } & $\begin{array}{c}\text { Nilai Buku } \\
\text { Sewa }\end{array}$ & $\begin{array}{c}\text { Saldo Piutang } \\
\text { Sewa }\end{array}$ & $\begin{array}{c}\text { Nilai Buku } \\
\text { Sewa }\end{array}$ & $\begin{array}{c}\text { Saldo Piutang } \\
\text { Sewa }\end{array}$ \\
\hline $\begin{array}{c}\text { 28-Feb- } \\
11\end{array}$ & Rp.305.472.624 & Rp.305.472.624 & Rp.305.472.624 & Rp.305.472.624 \\
\hline $\begin{array}{c}\text { 31-Des- } \\
11\end{array}$ & Rp.254.560.521 & Rp.241.832.484 & Rp.254.560.521 & Rp.266.263.410 \\
\hline 31Des-12 & Rp.193.465.997 & Rp.165.464.364 & Rp.193.465.997 & Rp.202.260.118 \\
\hline $\begin{array}{c}\text { 31-Des- } \\
\text { 13 }\end{array}$ & Rp.132.371.473 & Rp.89.096.244 & Rp.132.371.473 & Rp.114.035.262 \\
\hline $\begin{array}{c}\text { 28-Feb- } \\
14\end{array}$ & Rp.122.189.053 & 0 & Rp.122.189.053 & 0 \\
\hline
\end{tabular}

Sumber : PT BFI Finance Indonesia, Tbk. (data diolah)

Tabel di atas menunjukkan perbedaan dari perlakuan akuntansi transaksi sewa setelah dikoreksi, untuk nilai buku transaksi sewa tampak tidak terdapat perbedaan setelah dilakukan koreksi dan penyesuaian. Akan tetapi terdapat perbedaan yang cukup material pada piutang sewa selama periode leasing, hal ini disebabkan karena penerimaan pembayaran angsuran sewa dengan jumlah pokok piutang dan pendapatan bunga yang tetap sepanjang periode sewa. Sedangkan penulis mengusulkan untuk mencatat pokok penerimaan pembayaran sewa dan pendapatan bunga terhitung dari persentase atas saldo piutang sewa yang dilunasi oleh lessee.

Tabel 10

Pengaruh Transaksi Sewa Pada Laporan Laba Rugi Komprehensif (Rp)

\begin{tabular}{|c|c|c|c|c|}
\hline & Sebelum & Penyesuaian & Sesudah & Penyesuaian \\
\hline Tanggal & $\begin{array}{c}\text { Beban Depresiasi } \\
\text { Sewa }\end{array}$ & $\begin{array}{l}\text { Beban } \\
\text { Bunga }\end{array}$ & $\begin{array}{c}\text { Beban } \\
\text { Depresiasi } \\
\text { Sewa }\end{array}$ & $\begin{array}{l}\text { Beban } \\
\text { Bunga }\end{array}$ \\
\hline 2011 & Rp. 50.912.103 & Rp. 59.032.246 & Rp. 50.912.103 & Rp.34.601.320 \\
\hline 2012 & Rp. 61.094.524 & Rp. 54.186.460 & Rp. 61.094.524 & Rp.41.521.584 \\
\hline 2013 & Rp. 61.094.524 & Rp. 29.364.896 & Rp. 61.094.524 & Rp.41.521.584 \\
\hline 2014 & Rp. 10.182 .420 & Rp. 21.719.432 & Rp. 10.182 .420 & Rp. 6.920.264 \\
\hline
\end{tabular}

Sumber : PT BFI Finance Indonesia, Tbk. (data diolah)

Tabel 10 menggambarkan akibat dari perbedaan besarnya tarif bunga yang ditanggung oleh perusahaan lessee dengan usulan penulis, perusahaan menetapkan beban bunga tetap selama periode sewa sedangkan penulis mengusulkan untuk menghitung beban bunga dengan menggunakan metode anuitas. Oleh karena itu penulis mengusulkan untuk mendiskontokan 
tingkat bunga agar nilai uang dimasa yang akan datang dijadikan pada masa sekarang, sehingga beban bunga yang diterima lessee akan semakin menurun seiring dengan mengecilnya saldo piutang sewa. Dari tabel sesudah penyesuaian tampak pendapatan bunga yang semakin kecil sepanjang periode sewa, hal ini berarti membuka peluang perusahaan untuk mendapatkan laba yang lebih tinggi pada periode berikutnya.

\section{Simpulan dan Saran}

\subsection{Simpulan}

1. Perlakuan akuntansi yang diterapkan PT BFI Finance Indonesia, Tbk. atas aset yang diperoleh melalui kegiatan pembiayaan adalah dengan menggunakan metode sewa pembiayaan (capital lease) dan di depresiasi dengan metode garis lurus atau straight line method. Pada saat perjanjian leasing pembayaran uang muka sebagai simpanan jaminan, perusahaan mencatatnya pada kelompok aset lancar, sehingga di laporan posisi keuangan jumlah aset lancar lebih besar dari yang sebenarnya.

2. Pencatatan atas biaya bunga yang dibayar oleh lessee selama masa sewa ditentukan atas dasar nilai yang tetap untuk setiap periode yang diperhitungkan terhadap jumlah pembayaran sewa minimum dalam tahun yang bersangkutan. Pembebanan bunga dengan tingkat bunga tetap mengabaikan adanya "time value of money" yaitu nilai uang pada saat sekarang yan lebih tinggi dari pada masa yang akan datang dan perlakuan ini menyimpang.

3. Terdapat perbandingan antara perlakuan akuntansi sewa yang diterapkan oleh perusahaan dengan perlakuan akuntansi menurut PSAK NO.30.

a. Pengaruh transaksi sewa pada laporan posisi keuangan sebelum penyesuain dan setelah penyesuaian,untuk nilai buku sewa tampak tidak terdapat perbedaan setelah dilakukan koreksi dan penyesuaian. Akan tetapi terdapat perbedaan yang cukup material pada pendapatan sewa selama periode leasing, hal ini disebabkan perusahaan menetapkan pembayaran angsuran sewa dengan pokok kewajiban dan beban bunga yang tetap sepanjang periode sewa terhadap lessee.

b. Pengaruh transaksi sewa pada laporan laba rugi komprehensif sebelum penyesuain dan setelah penyesuaian, terdapat perbedaan besarnya tarif bunga dalam periode leasing.

\subsection{Saran}

Adapun saran yang dapat penulis sampaikan sehubungan dengan permasalahan penelitian ini yaitu sebagai berikut :

1. Bagi Perusahaan

Perusahaan sebaiknya menerapkan secara konsisten PSAK No. 30 yaitu menghitung bunga dengan mendiskontokan tingkat bunga dengan menggunakan metode anuitas.

2. Bagi Penelitian Selanjutnya

Peneliti selanjutnya disarankan untuk meneliti perusahaan yang telah konsisten menerapkan PSAK No.30. Dan memperoleh data yang lebih dari penelitian ini karena penelitian ini data yang diperoleh kurang mencukupi serta menggunakkan PSAK No.30 yang terbaru selanjutnya. 
VI. DAFTAR PUSTAKA

Dwi Martani, Dkk. 2012.Akuntansi Keuangan Menengah Berbasis PSAK. Selemba Empat, Jakarta.

Hery dan Widyawati. 2011.Akuntansi Keuangan Menengah 2. Bumi Aksara, Jakarta.

Ika Mira Kesuma. 2008. Skripsi Penerapan PSAK No.30 Tentang Akuntansi Leasing ditinjau dari pihak Lessor. Universitas Sumatra Utara, Medan.

Ikatan Akuntansi Indonesia. 2012. Standar Akuntansi Keuangan. Dewan Standar Akuntansi Keungan Ikatan Akuntansi Indonesia, Jakarta.

Indira Respati Sekarini. 2010. Analisis atas Penerapan PSAK 30 (Revisi 2007) pada Perusahaan Leasing dalam Pelaporan Keuangan PT. XXFI. Laporan Magang Program Sarjana Unversitas Indonesia, Jakarta.

Irene Herminda Runtuwene. 2013. Skripsi Penerapan Akuntansi Leasing Untuk Perencanaan dan Pengendalian pada PT.SFI Cabang Manado. Samratulangi, Manado.

Kasmir.2014. Analisis Laporan Keuangan. Rajagrafindo Persada, Jakarta.
Kieso, Donald. E dan Jery J.Weygandt.2002.Akuntansi Intermediate. Erlangga, Jakarta.

Martono. 2013.Bank dan Lembaga Keuangan Lainnya. Ekonisa. Jogyakarta.

Situmorang Monang. 2012. Handout Akuntansi Keuangan.

Nelson Lam dan Peter Lau. 2014. Akuntansi Keuangan Intermediate Financial Reporting. Selemba Empat, Jakarta.

Ria Christine Kombaitan . 2009. Skipsi Penerapan PSAK No.30 Tentang Perlakuan Akuntansi Sewa Aktiva Tetap pada PD.Bangun Bitung. Samratulangi, Manado.

Ria Dwiyanti Samudra. 2008. Skripsi Penerapan PSAK No.30 Mengenai Perlakuan Akuntansi Sewa GunaUsaha Aktiva Tetap dan Pengaruhnya pada Neraca dan Laporan Laba Rugi Pada Perusahaan.Universitas Brawijaya, Malang.

Sedarmayanti dan Syarifudin. 2011. Metode Penelitian.Bandung. Mandar Maju, Bandung.

Situmorang Shaolin. 2008. Penerapan PSAK No.30 Mengenai Akuntansi Leasing pada PT.Swadharma Indatama,

Medan. 